\title{
Transnational diaspora diplomacy, emotions and COVID-19: the Romanian diaspora in the UK
}

\author{
Alina Dolea ${ }^{1}$ (D) \\ Revised: 17 September 2021 / Accepted: 26 September 2021 / Published online: 26 October 2021 \\ (c) The Author(s), under exclusive licence to Springer Nature Limited 2021
}

The COVID-19 pandemic pushed irreversibly for expanding disciplinary boundaries to study diaspora diplomacy (Brinkerhoff 2019; Ho and McConnell 2017). Diaspora was placed in an unprecedented global spotlight, revealing a wide range of positionings in relation to home and host state. To understand these developments, public diplomacy (PD) needs a shift of focus: a diaspora-centred and transnational analytical approach to unpack the seeming 'uniformity' of diaspora and the homeland loyalties conflated in the concept of citizen diplomat that obscure contestation from within. Diasporas might be agents, instruments, and partners in PD, but they are also disruptors. Diasporas generate disruption and become a problem in PD, exposing the tensions, conflicts, protests emerging from domestic (and transnational) publics that PD scholarship has largely avoided. I will use this approach in a case study of the Romanian diaspora in the UK, informed by a research project conducted between 2018 and $2019 .{ }^{1}$

\section{Romanian diaspora is fifth largest in the world and growing}

90\% of the Romanian diaspora is in Europe, with the largest communities in Italy, Spain, Germany, UK and France (OECD 2019). The growing Romanian diaspora is estimated at over 5 million people, a quarter of Romania's population, but official statistics are incomplete due to the complexity and circular nature of Romanian migration (Sandu 2021). This impacts the Romanian consular network with infrastructure designed for smaller communities, as well as the policies on the ground. The Romanian government's main

Alina Dolea

edolea@bournemouth.ac.uk

1 Faculty of Media and Communication, Bournemouth University, Talbot Campus, Fern Barrow, Poole BH12 5BB, Dor, UK diaspora policy has been the return of migrants, to tackle the demographic decline, brain drain, labour force shortages and included fiscal facilities, tax rebates, or sectorial grants. Despite positive results of programmes aimed at highly skilled migrants (Anghel and Roman 2021), there is no evidence on the number and proportion of return migration (Anghel and Coşciug 2018). The pandemic might change that, but it is still too early to draw conclusions.

\section{Brexit and COVID-19: engagement with diaspora}

The Romanian Government's COVID-19 measures for diaspora included dedicated phone lines, repatriation flights, and task forces on the ground in the countries with large Romanian communities. A special COVID-19 section on the website of the Ministry of Foreign Affairs was created with regular travel updates, changes to quarantine or testing rules. An integrated platform, Diaspora hub, was also launched to provide personalized info.

In the UK, the pandemic accelerated the digitalization of diaspora communication: the website and Facebook pages of the Romanian Embassy and Consulate in London became primary sources of official information, providing timely and constant updates on travel rules and legal restrictions in both Romania and the UK. Equally central in their communication were the post-Brexit registration for the EU settlement scheme and the changes to immigration and work visa needed after December 2020. The Romanian honorary consuls have used their Facebook accounts to roll over the official information.

The model of communication changed from a previously dominant unidirectional dissemination of information to engagement with the community which doubled their number of followers. In fact, the most significant change was the

\footnotetext{
1 The research was supported by a grant of the Romanian Ministry of Research and Innovation, CNCS - UEFISCDI, project number PNIII-P1-1.1-PD-2016-2167 within PNCDI III.
} 
collaborative and partnership approach of the Romanian diplomatic institutions in relation to diaspora: the live sessions of dialogue with diaspora on consular issues, as well as live joint sessions with journalists and diaspora organizations on post-Brexit rights, visas and travel generated consistently the highest engagement.

Occasionally, high rates of online engagement were obtained in the context of the National Day, Christmas, or Easter holidays. However, the most successful initiative was the video series "Who is Romania" of the Romanian Cultural Institute in London, portraying Queen Marie, George Enescu or Constantin Brâncuşi: while aimed at British audiences, it had an online community fostering role. The Romanian-British Literature Festival, Romania Rocks, that featured live Facebook talks of well-known Romanian and British authors also fulfilled this role.

\section{Diaspora from within: belonging and rejection both 'here' and 'there'}

The Romanian diaspora in the UK is heterogeneous and diverse: most Romanians work in construction, real estates and business, hospitality and tourism, healthcare and NHS, commerce and transportation; there are categories of highly skilled, entrepreneurs and professionals, low skilled, but also vulnerable migrants. Their immigration motivations, as well as their life experiences in the UK are very different. What they have in common is a sense of loss of roots, of the familiar environment or even of social status and the constant tensions of belonging here and there, neither here nor there. There is also a lot of cognitive dissonance as power distance between institutions and citizens is lower in the UK than in Romania: the diplomatic and consular network replicates a bureaucratic, high power distance in relation to its diasporic citizens; modernization is happening, but institutional inertia is high and the accelerated diaspora growth led to consular services demand exceeding by far the offer; furthermore, Romanian diaspora institutions did not assume a cultural mediator role. Consequently, there is a sense of alienation and frustration.

Romanian diaspora's existence is highly mediated by media and social media: while their media consumption varies greatly, Romanian migrants watch British and Romanian TV channels through satellite TV, get their news from Facebook, are members of the different communities of "Romanians in UK" or talk with family and friends 'here' and 'there'. The various British media and political campaigns against immigration reached them either directly, or through their informal networks of friends and colleagues.

The transnational ties of Romanian diaspora with homeland and the UK are even more complex as in Romanian society there is a gradual "othering" of Romanian migrants and a dichotomic public discourse: migrants are either "good" or "bad". After 2000 when emigration intensified, the media have contributed heavily to stirring emotions of collective pride, shame, or inferiority complexes in relation to migrants, while political parties have heavily instrumentalized diaspora for electoral gains, making promises that were not kept.

In a series of truly unfortunate events, Brexit and COVID19 augmented the emotions and feelings of alienation and rejection of Romanians by both home and host state: the Romanian President appealed to Romanian diaspora to not come home for the 2020 Easter; a member of the Romanian Parliament singled out returning migrants for spreading the virus, while a Romanian mayor stated the spike in infections in his town was due to return migrants who broke quarantine rules; Romanians at home took to Facebook with anger and even hateful comments at the return Romanians to stay away. In the UK, the Romanian Consulate had to close in line with the UK Government's restrictions, leading to delays of several months in processing IDs necessary for EU settlement scheme registration. As the UK economy stopped during the lockdown, the Romanians employed in construction, hospitality and tourism lost their jobs and had to return to Romania. The numerous online communities "Romanians in UK" as well as the pages of the Romanian Embassy and Consulate in London became arenas of contestation of Romanian and British governmental policies on pandemic, vaccination, and diaspora.

Paradoxically, Brexit and COVID-19 are forging the community: as Home Office updates (2021) indicate over 1 million Romanians living in the UK, the fragmented diaspora has started to gradually coagulate and gain a certain self-awareness and visibility. Online, solidarity initiatives have emerged for those affected by COVID-19 and microinfluencers gained momentum, vlogging to Romanian audiences at home and in the UK about travel rules and the EU settlement scheme. Offline, there was an incredible mobilization of various Romanian associations to support especially the vulnerable migrants (Martinescu and Balațchi-Lupascu 2020). Romanians are becoming more civically engaged, politically active (Vathi and Trandafoiu 2020), interested in political and administrative representation: 3 Romanians ran and were elected in the May 2021 UK local elections.

\section{Instrumentalizing diaspora emotions and the rise of far-right}

While the global pandemic unfolded, the Romanian diaspora voted in the December 2020 Romanian parliamentary election for a far-right party: the Alliance for the Unity of Romanians (AUR) secured a surprising $9 \%$ of total votes and became the 4th political party in Romania. The party 
got $23 \%$ of all votes expressed by Romanians abroad, ranking $3 \mathrm{rd}$ in their preferences. This victory came as a total surprise: the party was only formed in 2019 and ran under the radar, as it wasn't even included in polls; diaspora had a record turnout and signalled a changing trend as it traditionally voted massively for liberal parties (Bortun 2020). In the UK, where the party was officially launched with a first branch opened in Wolverhampton, AUR came second with $25.66 \%$ votes (turnout $31 \%$ ).

AUR stands for family, nation, faith and liberty and its campaign programme explicitly appeals to diaspora, invoking the discrimination of Romanians both in the states of residence and in Romania. During the pandemic, AUR also positioned itself against mask wearing, restrictions and compulsory vaccinations, leading such protests in Romania.

AUR instrumentalized heavily the emotional costs of migration (fear, shame, the need for validation and appreciation of migrants), the constant identity negotiations, the "in-betweenness" of migrants, the idyllic home (reimagined by migrants through nostalgia, affect and memory), the feelings of loneliness, abandonment, and rejection (both here and there) and the need for roots.

\section{Lessons for the present}

Analysing diaspora from within brings to the fore the longignored feelings and emotions of migrants. These were certainly augmented in times of social and symbolic distancing, but it would be a mistake to dismiss them as pandemic related only.

Situating diaspora in transnational social fields (Faist and Baucöck 2010) that connect their places of origin and destination, PD scholars can understand the social consequences of diaspora's split existence. Investigating the complex web of transnational diaspora relations and ties that are diplomatic, economic, social, political, but also emotional, can ultimately advance the study and policy making in diaspora diplomacy.

\section{References}

Anghel, R.G., and A. Coşciug. 2018. Patterns and Mechanisms of Return Migration to Romania. In Remigration to Post-Socialist Europe: Hopes and Realities of Return, 3rd ed., ed. C.H. Tomić, R. Pichler, and S. Scholl-Schneider. Wien: Wien, LIT (Erste Foundation series).

Anghel, R.G., and M. Roman. 2021. Lessons from Romania on Highly Qualified Returnees: Processes, Policies, Effects. In Emigration from the Western Balkans, ed. H. Brey, C. Hagemann, V. Esch, and V. Pal, 95-101. Muenchen: Südosteuropa-Gesellschaft.

Brinkerhoff, J.M. 2019. Diasporas and public diplomacy: Distinctions and future prospects. The Hague Journal of Diplomacy. 14: 51-64. https://doi.org/10.1163/1871191X-14101015.

Bortun, V. 2020. Romanian legislative elections in the diaspora: record participation and the emergence of the nationalist vote. MIGRADEMO Blog posts. https://migrademo.eu/romanian-legislative-elect ions-in-the-diaspora-record-participation-and-the-emergence-ofthe-nationalist-vote/

Faist, T., and R. Baucöck. 2010. Diaspora and Transnationalism: Concepts, Theories and Methods (IMISCOE Research). Amsterdam: Amsterdam University Press.

Ho, E., and F. McConnell. 2017. Conceptualizing 'diaspora diplomacy' Territory and populations betwixt the domestic and foreign. Progress in Human Geography. https://doi.org/10.1177/0309132517 740217.

Home Office. 2021. EU Settlement Scheme Statistics. https://www.gov. uk/government/collections/eu-settlement-scheme-statistics.

Martinescu, A., and A. Balatchi-Lupascu. 2020. Understanding the Romanian Diaspora: Diaspora Mobilisation During COVID-19. The Foreign Policy Center. https://fpc.org.uk/understanding-theromanian-diaspora-diaspora-mobilisation-during-covid-19/\# $\mathrm{ftn} 10$

OECD. 2019. Talent Abroad: A Review of Romanian Emigrants. Paris: OECD Publishing. https://doi.org/10.1787/bac53150-en.

Sandu, D. 2021. Noile diaspore româneşti între aici şi acolo. In A. Ricci, Ed. Românii în Italia. IDOS. Pre-print. https://www.resea rchgate.net/publication/346247408_Noile_diaspore_romanesti_ intre_aici_si_acolo_2020

Vathi, Z., and R. Trandafoiu. 2020. EU nationals in the UK after BREXIT: Political engagement through discursive awareness, reflexivity and (in)action. Journal of Language and Politics 19 (3): 479-497. https://doi.org/10.1075/jlp.19028.vat.

Publisher's Note Springer Nature remains neutral with regard to jurisdictional claims in published maps and institutional affiliations.

Alina Dolea is Principal Academic at Bournemouth University, UK. Her research is situated at the intersection of public diplomacy, migration, media and communication studies, with a focus on discourse. She is particularly interested in the role non-state actors have come to play in public diplomacy, reproducing, but also contesting and disrupting the state's strategic communication. She is currently focusing on diasporas and emotions, exploring the opportunities as well as the consequences of their transnational existence for public diplomacy. Alina was Fulbright Senior Scholar 2015-2016 at USC Annenberg School for Communication and Journalism (USA), as well as SCIEX Postdoc Visiting Scholar 2015 at the University of Fribourg (Switzerland). She is the recipient of the European Public Relations Education and Research Association (EUPRERA) $2015 \mathrm{PhD}$ Award for Excellent Doctoral Theses for her $\mathrm{PhD}$ theses "Country promotion as a public issue in Romania after 1989 - A social constructivist and interdisciplinary approach". Alina is one of the founders of the Public Diplomacy Interest Group within the International Communication Association. 